\title{
PENGEMBANGAN BAHAN AJAR PERSIAPAN PPL UNTUK MAHASISWA PGSD YANG MENGAKOMODASI DIVERSE LEARNERS
}

\author{
Rahayu Condro Murti, Unik Ambarwati, dan Safitri Yosita Ratri \\ Universitas Negeri Yogyakarta \\ Email: rahayu_condro@uny.ac.id
}

\begin{abstract}
Abstrak
Tujuan penelitian ini adalah mengembangkan bahan ajar pembelajaran Sekolah Dasar yang mengakomodasi Diverse Learners yang layak untuk dosen Pendidikan Guru Sekolah Dasar. Subyek dalam penelitian ini adalah dosen Pendidikan Guru Sekolah Dasar (PGSD) yang terdiri dari 2 dosen pembelajaran IPS, 2 dosen Pembelajaran Matematika, dan 1 dosen Pendidikan. Penelitian ini dilaksanakan di PGSD UNY dengan menggunakan metode penelitian dan pengembangan (R\&D). Tahapan dalam penelitian ini terdiri dari: 1) analisis kebutuhan, 2) pengembangan desain produk, 3) evaluasi formatif produk awal. Proses validasi dilakukan oleh 1 orang ahli materi dan 1 orang ahli media. Subyek uji coba yang terdiri dari 2 dosen pembelajaran IPS, 2 dosen Pembelajaran Matematika, dan 1 dosen Pendidikan. Pengumpulan data evaluasi formatif dilakukaan dengan menggunakan lembar penilaian untuk aspek kualitas tampilan, penyajian materi, dan proses belajar. Hasil penelitian menunjukkan bahwa: Pengembangan bahan ajar ini melalui uji validasi materi, uji validasi media, dan focus group discussion (FGD) layak untuk digunakan. Pada validasi materi diperoleh skor rata-rata 2,35 (cukup) pada uji pertama dan rata-rata menjadi 2,6 (baik) pada uji kedua, sedangkan pada uji validasi oleh ahli media diperoleh skor rata-rata 2,6 (kategori baik) pada uji pertama dan 3,6 (kategori sangat baik) pada uji validasi kedua. Adapun rata-rata hasil penilaian keterbacaan pengguna, dalam hal ini, dosen PGSD yang terkait dengan isi bahan ajar, yaitu dosen tentang konsep diverse learners (3,0-baik), pendidikan matematika SD (3,53-kategori sangat baik), dan Pembelajaran IPS di SD (3,0baik). Dengan demikian diharapkan bahan ajar ini menunjang pelaksanaan PPL mahasiswa PGSD dalam mempersiapkan mereka melaksanakan pembelajaran yang mengakomodasi diverse learners di sekolahnya masing-masing.
\end{abstract}

Kata kunci: Pengembangan, Bahan ajar, Diverse learners

\section{DEVELOPMENT OF PPL TEACHING MATERIALS FOR ELEMENTARY TEACHER STUDENT'S THAT ACCOMMODATE THE DIVERSE LEARNERS}

\begin{abstract}
The purpose of this research is to develop teaching materials of Elementary School which accommodate the appropriate Diverse Learners for lecturers of Elementary School Teacher Education. Subjects in this research are lecturer of Elementary School Teacher Education (PGSD) consisting of 2 lecturers of IPS study, 2 lecturers of Mathematics Learning, and 1 lecturer of Education. This research was conducted in PGSD UNY using research and development ( $R \& D)$ method. Stages in this study consist of: 1) needs analysis, 2) product design development, 3) formative product evaluation early. The validation process is done by 1 material expert and 1 media expert. The test subjects consist of 2 lecturers of IPS study, 2 lecturers of Mathematics Learning, and 1 lecturer of Education. Formative evaluation data collection is done by using assessment sheets for aspects of display quality, material presentation, and learning process. The results showed that: Development of this resource through material validation test, media validation test, and focus group discussion (FGD) is feasible to be used. Material validation obtained an average score of 2.35 (enough) in the first test and the average to 2.6 (good) in the second
\end{abstract}


test, whereas in the validation test by the expert media obtained an average score of 2.6 (good category) On the first test and 3.6 (very good category) on the second validation test. As for the average user's readability assessment results, in this case, PGSD lecturers are related to the content of teaching materials, ie lecturers on the concept of diverse learner (3.0-good), elementary mathematics education (3.53-excellent category), and Learning IPS in SD (3.0-good). It is hoped that this teaching material will support the implementation of PPG PGSD students in preparing them to carry out the lessons that accommodate diverse learners in their respective schools.

Keyword: development, learning materials, diverse learners

\section{PENDAHULUAN}

Perbedaan yang dimiliki oleh siswa meliputi; kebudayaan dan bahasa, kemampuan akademik, minat, latar belakang sosial, dan siswa dengan kebutuhan khusus. Beragamnya kondisi siswa terkadang menyulitkan guru dalam pengelolaan kelas. Hal ini telah dibuktikan dengan penelitian Andyarto Surjana bahwa kemampuan guru dalam mengelola kelas belum optimal hanya mencapai $37 \%$.

Ketidakmampuan guru dalam mengelola perbedaaan tersebut akan berimplikasi tidak terlayaninya kebutuhan siswa dengan baik. Kebutuhan siswa tidak hanya terbatas pada anak-anak yang mempunyai ke'tuna'an tapi juga kesulitan lain yang tidak tampak karena guru tidak mampu mengenalinya. Hasil penelitian, invisible disability yang ada di Amerika 90\%. Persepsi guru tentang keberhasilan siswa masih terbatas pada pencapaian yang bersifat kuantitatif, bukan pada pengembangan potensi. Jika ada siswa yang tidak memperhatikan, mengganggu di kelas mereka menjustifikasi bahwa mereka anak yang bodoh. Anak-anak yang mempunyai 'Disability Invisible' ini juga mendapat perlakuan yang tidak adil. Penelitian Pujaningsih dkk (2013) menemukan bahwa ada siswa SD yang dipindahkan sekolah hingga 3 kali karena takut mempengaruhi nilai UN di sekolah tersebut.

Permasalahan tersebut juga terjadi pada calon guru yang praktik mengajar di sekolah-sekolah mitra UNY. Hasil pertemuan pihak fakultas dengan kepala sekolah, guru, dan alumni menyatakan bahwa kemampuan mahasiswa PPL dalam mengakomodasi perbedaan individu belajar masih belum optimal. Indikator yang bisa diamati dari ketidakmampuan mahasiswa saat mengajar adalah mereka menggunakan 1 Lembar Kerja Siswa (LKS) untuk semua, tanpa mempertimbangkan bahwa ada beberapa siswa yang masih kesulitan dalam belajarnya sehingga bisa diakomodasi dengan LKS yang berbeda.

Kampus pendidikan yang mencetak guru profesional harus menyiapkan mahasiswanya untuk terlibat pada pengajaran yang secara konsisten terlibat dengan semua siswa dalam aktivitas intelektual yang tepat. Salah satu kemampuan yang harus dimiliki adalah memiliki semua level ketrampilan yang bermakna dengan dukungan yang berbedabeda untuk mencapai tujuan. Untuk itu dosen PGSD harus memahami secara teoritik tentang konsep diverse learners, dan implementasinya dalam pembelajaran. Penelitian ini bertujuan untuk mengembangkan bahan ajar SD yang memuat tentang konsep, karakteristik, pembelajaran dan contoh Rencana Pelaksanaan Pembelajaran IPS yang mengakomodasi diverse learners.

Dengan demikian identifikasi masalah kajian ini adalah mengenai pemahaman mahasiswa saat PPL tentang menangani siswa yang berbeda-beda masih kurang, kemudian belum adanya materi khusus perkuliahan tentang diverse learners yang disampaikan kepada mahasiswa, dan terakhir belum adanya pengintegrasian konsep diverse learners pada 5 bidang studi SD. Sehingga rumusan masalahnya adalah bagaimana 
mengembangkan bahan ajar yang layak pada materi pembelajaran SD yang dapat mengakomodasi diverse learners? Dari kajian ini didapatkan manfaat penelitian 1) membekali konsep diverse learners pada mahasiswa untuk persiapan PPL, 2) mengintegrasikan konsep diverse learners pada mata kuliah 5 bidang studi, 3) memberikan contoh implementasi pengintegrasian konsep diverse learners pada mata kuliah strategi pembelajaran, pembelajaran Matematika, dan pembelajaran IPS.

\section{Konsep Diverse Learners}

Konsep diversity (keragaman), menemukan beberapa konsep di antaranya menurut Dimitrova et. al. (2003:34) dapat dijelaskan sebagai keragaman yang dapat terdiri dari beberapa hal yaitu: (a) etnis, gender, agama, disabiliti; (b) bahasa, kebudayaan, komunitas; (c) pengetahuan dasar, gaya belajar, pendekatan belajar individual; (d) motivasi dan ekspetasi personal; dan (e) konteks sosial pendidikan, dan gaya hidup seseorang. Dalam pembelajaran diversity, siswa di kelas pada dasarnya memiliki keterbatasan atau kesulitan belajar terkait dengan keragaman yang disebutkan di atas. Kebudayaan, keluarga, sosiologi, politik, dan pendidikan yang ada dalam kehidupan siswa di luar sekolah akan berpengaruh terhadap cara siswa belajar tentang dunia dan diri mereka sendiri saat berada di dalam sekolah.

Bagi seorang guru, memahami akan diversity dalam pembelajaran menjadi sangat penting. Pada tahun 2010 International Reading Association menambahkan diversity sebagai standar yang terpisah pada standar yang telah direvisi pada Standart for Reading Profesional. Hasil penelitian menyebutkan bahwa keyakinan guru tentang diversity penting karena dapat berpengaruh pada kebijakan yang berkaitan dengan siswa, terutama pada aspek budaya, bahasa, ekonomi, dan perbedaan etnis, contohnya, jika guru mempunyai pengalaman yang terbatas atau pengalaman negatif tentang kebudayaan lain, maka itu akan mempengaruhi kesempatan siswa untuk belajar.

Hal ini sejalan dengan pemikiran Bates \& Rosaen (2010:47) bahwa memahami diversity kaitannya dengan diverse learners (siswa yang beragam) akan sangat penting dan sebaiknya menjadi pusat pembelajaran karena latar belakang pembelajar akan mempengaruhi kebermaknaan pembelajaran. Bates \& Rosaen (2010:49) menambahkan bahwa seringkali orang hanya berasumsi bahwa para siswa sudah mampu belajar namun sebetulnya ada masalah kesulitan belajar. Dengan bertambahanya pemahaman guru akan keragaman siswa, seorang guru akan semakin mampu untuk membuat pembelajaran lebih bermakna. Ada beberapa topik diverse learners yang menjadi kajian di Michigan State University di antaranya language and cultural (bahasa dan budaya), special needs (siswa berkebutuhan khusus) dan interest (minat siswa).

Dalam persiapan supaya mahasiswa dapat mengakomodasi siswa yang beragam (diverse learners) di kelas praktikum maupun saat menjadi guru nanti, matakuliah di atas memberikan tugas bagi mereka untuk menyusun RPP sebelum terjun di sekolah. Carey Symons salah seorang pengajar TE405 menyatakan bahwa, sebelum mulai mengajar terlebih dahulu mahasiswa akan menyusun RPP yang mengakomodasi adanya siswa yang beragam. Mereka membantu guru dalam menangani anak yang memiliki kesulitan analisis membaca (reading analysis) dan memahami bacaan (reading comprehension). Beberapa tantangan yang dihadapi mahasiswa adalah mereka harus mampu memahami terlebih dahulu bagaimana karakteristik individu terkait kemampuan mereka dan latar belakang mereka sehingga terbangun hubungan emosional antara mahasiswa calon guru dan siswa.

Semua siswa harus diberi pengalaman sukses, membangun harapan dan visi untuk masa depan yang positif dan 
belajar untuk mengapresiasi nilai-nilai perbedaan dalam hidup mereka tanpa membedakan budaya, bahasa, dan profil belajar mereka. Perbedaan yang terdapat pada siswa meliputi: Etnis, Gender, Agama, Disabiliti, Bahasa, Kebudayaan, Komunitas, Pengetahuan dasar, gaya belajar, pendekatan belajar individual, Motivasi dan ekpetasi personal, kontek sosial pendidikan, dan gaya hidup seseorang. Jenis keragaman yang akan dibahas pada penelitian ini dibatasi pada perbedaan gaya belajar, perbedaan cara berpikir, kecerdasan ganda, identifikasi bakat dan minat, serta anak berkesulitan belajar.

\section{Kajian tentang Modul}

Modul adalah salah satu bahan ajar yang penting untuk digunakan siswa sebagai sumber belajar. Modul merupakan bahan ajar cetak yang dirancang untuk dapat dipelajari secara mandiri oleh pengguna modul. Modul disebut juga media untuk belajar mandiri karena di dalamnya telah dilengkapi petunjuk untuk belajar sendiri. Artinya, siswa dapat melakukan kegiatan belajar tanpa kehadiran guru secara langsung. Dikmenjur mengartikan modul sebagai salah satu bentuk bahan ajar yang dikemas secara utuh dan sistematis, di dalamnya memuat seperangkat pengalaman belajar yang terencana dan didesain untuk membantu siswa menguasai tujuan belajar yang spesifik.

Pembelajaran dengan modul adalah pendekatan pembelajaran mandiri yang berfokuskan penguasaan kompetensi dari bahan kajian yang dipelajari siswa dengan waktu tertentu sesuai dengan potensi dan kondisinya. Sistem belajar mandiri adalah cara belajar yang lebih menitikberatkan pada peran otonomi belajar siswa. Belajar mandiri adalah suatu proses di mana individu mengambil inisiatif dengan atau tanpa bantuan orang lain untuk mendiagnosa kebutuhan belajarnya sendiri, merumuskan/menentukan tujuan belajarnya sendiri, mengidentifikasi sumber-sumber belajar, memilih dan melaksanakan strategi belajarnya, dan mengevaluasi hasil belajarnya sendiri. Secara umum, pembelajaran menggunakan modul bermanfaat untuk hal-hal sebagai berikut: 1) Meningkatkan efektivitas pembelajaran tanpa harus melalui tatap muka secara teratur karena kondisi geografis, sosial ekonomi, dan situasi masyarakat, 2) Menentukan dan menetapkan waktu belajar yang lebih sesuai dengan kebutuhan dan perkembangan belajar siswa, 3) Secara tegas mengetahui pencapaian kompetensi peserta didik secara bertahap melalui kriteria yang telah ditetapkan dalam modul, 4) Mengetahui kelemahan atau kompetensi yang belum dicapai peserta didik berdasarkan kriteria yang ditetapkan dalam modul sehingga tutor dapat memutuskan dan membantu siswa untuk memperbaiki belajarnya serta melakukan remediasi.

Karakteristik modul yang dimaksud sebagai berikut:

1. Self Instruction; Merupakan karakteristik penting dalam modul, dengan karakter tersebut memungkinkan siswa dapat belajar secara mandiri dan tidak tergantung pada pihak lain untuk memenuhi karakter self instructional, maka dalam modul harus: a. berisi tujuan yang dirumuskan dengan jelas; $b$. berisi materi pembelajaran yang dikemas ke dalam unit-unit kecil/spesifik sehingga memudahkan belajar secara tuntas; c. menyediakan contoh dan ilustrasi yang mendukung kejelasan pemaparan materi pembelajaran; d. menampilkan soal-soal latihan, tugas dan sejenisnya yang memungkinkan pengguna memberikan respon dan mengukur tingkat penguasaannya; e. kontekstual yaitu materi-materi yang disajikan terkait dengan suasana atau konteks tugas dan lingkungan penggunanya; $f$. menggunakan bahasa yang sederhana dan komunikatif; g. terdapat rangkuman materi pembelajaran; $h$. terdapat instrumen penilaian/assessment, yang memungkinkan siswa melakukan "self 
assessment'; i. terdapat instrumen yang dapat digunakan penggunanya mengukur atau mengevaluasi tingkat penguasaan materi; j. terdapat umpan balik atas penilaian, sehingga penggunanya mengetahui tingkat penguasaan materi; $\mathrm{k}$. tersedia informasi tentang rujukan/pengayaan/referensi yang mendukung materi pembelajaran dimaksud.

2. Self Contained; Modul dikatakan self contained bila seluruh materi pembelajaran yang dibutuhkan oleh siswa termuat dalam modul tersebut. Self Contained yaitu seluruh materi pembelajaran dari satu unit kompetensi atau sub kompetensi yang dipelajari terdapat di dalam satu modul secara utuh. Tujuan dari konsep ini adalah memberikan kesempatan siswa mempelajari materi pembelajaran yang tuntas, karena materi dikemas ke dalam satu kesatuan yang utuh. Jika harus dilakukan pembagian atau pemisahan materi dari satu unit kompetensi harus dilakukan dengan hati-hati dan memperhatikan keluasan kompetensi yang harus dikuasai. Modul dapat dikatakan self contained jika terdapat: a. tujuan pembelajaran/kompetensi; b. prasyarat yaitu materi-materi pelajaran yang mendukung atau perlu dipelajari terlebih dahulu sebelumnya; c. prosedur pembelajaran; d. materi pembelajaran yang tersusun sistematis; e. latihan/tugas-tugas; f. soal-soal evaluasi beserta kunci jawaban dan tindak lanjut yang harus dikerjakan oleh siswa.

3. Berdiri Sendiri (Stand Alone); Modul yang tidak tergantung bahan ajar/media lain, atau tidak harus digunakan bersama-sama dengan bahan ajar/media lain. Untuk memenuhi karakterisitk berdiri sendiri (stand alone), maka modul tersebut harus memenuhi kriteria dibawah ini: a. Dapat digunakan tanpa tergantung pada media lain seperti kaset audio, multimedia interaktif dan media lainya; b. Jika masih menggunakan dan bergantung pada media lain selain modul yang digunakan, maka media tersebut tidak dikategorikan sebagai media yang berdiri sendiri.

4. Adaptif; Modul hendaknya memiliki daya adaptasi yang tinggi terhadap perkembangan ilmu dan teknologi. Modul akan dikatakan adaptif jika dapat memenuhi unsure-unsur di bawah ini: a. memperhatikan percepatan perkembangan ilmu dan teknologi pengembangan modul multimedia hendaknya tetap "up to date"; b. serta fleksibel digunakan; c. isi materi pembelajaran dapat digunakan sampai dengan kurun waktu tertentu.

5. User Friendly; Modul hendaknya juga memenuhi kaidah user friendly atau bersahabat/akrab dengan pemakainya. Modul akan dikatakan user friendly jika setiap instruksi dan paparan informasi yang tampil bersifat membantu dan bersahabat dengan pemakainya, termasuk hal-hal di bawah ini: a. kemudahan pemakai dalam merespon; b. mengakses sesuai dengan keinginan; c. penggunaan bahasa yang sederhana, mudah dimengerti; d. penggunaan istilah yang umum.

\section{METODE}

Penelitian ini menggunakan penelitian dan pengembangan (Research and Developmentl $\mathrm{R} \quad \& \quad \mathrm{D})$ yang didefinisikan oleh Borg dan Gall sebagai " $a$ process used to develop and validate educational product". Produk yang ingin dihasilkan dalam penelitian ini berupa bahan ajar materi pembelajaran SD yang mengakomodasi diverse learners. Desain yang dipilih adalah desain R \& D (Gall, Gall \& Borg, 2003:164) dengan modifikasi.

Penelitian diselesaikan dalam 1 tahap penelitian yang diselesaikan dalam kurun waktu 6 bulan. Terdiri dari 4 langkah: 1) mengumpulkan materi atau bahan hasil review jurnal sebagai catatan lapangan observasi; 2) menetapkan dosen yang menjadi subyek penelitian yaitu sebanyak 5 orang; 3) memilih konsep diverse learners yang akan menjadi topik pengembangan yaitu perbedaan 
kemampuan, minat, dan berkesulitan belajar; 4) menentukan mata kuliah yang akan diintegrasikan dengan konsep diverse learners yaitu mata kuliah Strategi Pembelajaran, Pembelajaran Matematika, dan Pembelajaran IPS; 5) merancang bahan ajar yang mengakomodasi diverse learners; 6) desain layout dan grafis melibatkan ahli media; 7) FGD dengan expertise; 8) revisi bahan ajar yang mengakomodasi diverse learners.

Subjek uji coba dalam penelitian pengembangan yang dilakukan ini adalah 5 dosen PGSD FIP UNY, yang mengampu mata kuliah Strategi Pembelajaran, Pembelajaran Matematika, dan Pembelajaran IPS.

Jenis data yang digunakan dalam penelitian ini adalah jenis data kuantitatif yang dilengkapi dengan data kualitatif dan data dokumen proses. Data kuantitatif untuk menentukan kelayakan produk diperoleh dari nilai skor hasil angket penilaian oleh ahli materi, ahlimedia, dan subyek uji. Untuk data kualitatif juga dari hasil wawancara pada dosen yang menilai buku tersebut.

Kegiatan yang dilakukan peneliti pada tahap penyusunan instrumen penelitian ini antara lain: 1) analisis dokumen (aspek maupun indikator penilaian); 2) pembuatan kisi-kisi instrumen; 4) diskusi dengan teman sejawat; 5) pengetikan butir instrumen.

Data yang diperoleh melalui instrumen penilaian pada saat uji coba dan dianalisis dengan menggunakan statistik deskriptif kualitatif. Analisis ini dimaksudkan untuk menggambarkan karakteristik data pada masing-masing variabel. Dengan ini diharapkan akan mempermudah memahami data untuk proses analisis selanjutnya. Hasil analisis data digunakan sebagai dasar untuk merevisi produk bahan ajar yang dikembangkan.

\section{HASIL DAN PEMBAHASAN}

Bahan ajar berupa buku "Pembelajaran di Sekolah Dasar yang Mengakomodasi Diverse Learners" disusun berdasarkan analisis kebutuhan dari beberapa permasalahan yang ada dalam pelaksanaan program pengalaman lapangan (PPL) mahasiswa PGSD FIP UNY. Hasil pertemuan pihak fakultas dengan kepala sekolah, guru, dan alumni menyatakan bahwa kemampuan mahasiswa PPL dalam mengakomodasi perbedaan individu belajar masih belum optimal. Indikator yang bisa diamati dari ketidakmampuan mahasiswa saat mengajar adalah mereka menggunakan 1 Lembar Kerja Siswa (LKS) untuk semua, tanpa mempertimbangkan bahwa ada beberapa siswa yang masih kesulitan dalam belajarnya sehingga bisa diakomodasi dengan LKS yang berbeda.

Hasil wawancara dengan mahasiswa yang mengalami kesulitan dalam mengakomodasi Diverse Learners menunjukkan bahwa mereka tidak mempunyai bekal pengetahuan dan ketrampilan yang cukup saat perkuliahan di kampus. Materi yang berkaitan dengan identifikasi karakteristik siswa terdapat pada mata kuliah perkembangan peserta didik, Pendidikan Berkebutuhan Khusus dan Bimbingan Konseling di SD. Pada kenyataannya mata kuliah tersebut belum banyak memberikan pengalaman kepada mahasiswa dalam menangani diverse learners. Pada saat observasi pra PPL mahasiswa mengamati bagaimana guru mengajar dan lingkungan serta fasilitas sekolah dengan mengabaikan perilaku siswa saat belajar dan pengaruhnya terhadap proses pembelajaran.

Berdasarkan analisis kebutuhan di atas maka pengembangan bahan ajar yang berjudul "Pembelajaran di Sekolah Dasar yang Mengakomodasi Diverse learners" menjadi sangat penting dan dibutuhkan demi terciptanya pembelajaran yang mengakomodasi keberagaman siswa di kelas. Dalam hal ini, maka semua siswa berhak memperoleh pembelajaran yang sesuai dengan karakteristiknya. Keberagaman karakteristik yang dimaksud adalah keberagaman kemampuan, gaya belajar dan keberagaman motivasi dan keinginan. 
Kajian Produk

Produk yang dihasilkan dari penelitian ini berupa Bahan Ajar Pembelajaran di Sekolah Dasar yang Mengakomodasi Diverse Learners. Produk telah melalui tahap pengkajian Ahli
Materi, Ahli Media, dan Uji Keterbacaan dari para expert (penilai sesuai bidang). Dari penilaian di atas, nilai produk dapat dirangkum ke dalam Tabel 1 dan Tabel 2 berikut ini.

Tabel 1. Penilaian Bahan Ajar dari Ahli Materi dan Ahli Media

\begin{tabular}{rccc}
\hline Penilai & Tahap I & Tahap II & Kenaikan \\
\hline Ahli Materi & 2,35 (cukup) & 2,6 (baik) & 0,25 \\
Ahli Media & 2,6 (baik) & 3,9 (sangat baik) & 1,3 \\
\hline
\end{tabular}

Tabel 2. Keterbacaan Bahan Ajar oleh Expert

\begin{tabular}{llll}
\hline \multicolumn{1}{c}{ Penilai } & \multicolumn{1}{c}{ Tampilan } & \multicolumn{1}{c}{ Penyajian Materi } & \multicolumn{1}{c}{ Proses Belajar } \\
\hline $\begin{array}{l}\text { Konsep Diverse } \\
\text { Learners }\end{array}$ & 3,0 (baik) & 3,0 (baik) & 3,0 (baik) \\
Matematika & 3,0 (baik) & 4,0 (sangat baik) & 3,5 (sangat baik) \\
& 4,0 (sangat baik) & 3,7 (sangat baik) & 3,0 (baik) \\
IPS & 3,8 (sangat baik) & 3,6 (sangat baik) & 4,0 (sangat baik) \\
& 3,5 (sangat baik) & 3,3 (baik) & 3,5 (sangat baik) \\
\hline
\end{tabular}

Produk Bahan Ajar yang disusun dapat menjadi bahan belajar ataupun modul bagi dosen Program Studi PGSD khususnya bidang Matematika dan IPS yang membimbing mahasiswa PPL. Selain itu produk ini dapat sebagai sumber belajar mandiri bagi mahasiswa calon guru yang sedang melaksanakan PPL di Sekolah Dasar sehingga mampu lebih cepat memperluas akses pengetahuan dan mampu menerapkan dalam praktik pembelajaran di kelas yang mengakomodasi Diverse Learners. Produk ini memiliki kelebihan menyajikan latar belakang pengetahuan penyusun yang diperoleh selama pelatihan singkat di Michigan State University (MSU) Amerika Serikat. Produk sebagai contoh tampilan kegiatan pembelajaran sehingga dapat menjadi panduan pelaksanaan pembelajaran yang mengakomodasi diverse learners khususnya bidang Matematika dan IPS.

Setelah melalui tahap validasi ahli materi, ahli media, dan penilai dari dosen bidang studi, produk direvisi sesuai dengan saran-saran para ahli tersebut.
Berdasarkan hasil nilai para ahli, produk dapat dikategorikan sebagai bahan ajar yang layak diujicobakan. Oleh karena itu, sebagai perencanaan selanjutnya, produk akan di uji coba di semester depan pada mahasiswa PPL Prodi PGSD FIP UNY.

\section{PENUTUP}

Berdasarkan hasil penelitian dan pembahasan, dapat disimpulkan bahwa Pengembangan bahan ajar berupa buku dengan judul "Pembelajaran di Sekolah Dasar yang Mengakomodasi Diverse learners" layak untuk digunakan sebagai salah satu sumber belajar yang digunakan dosen untuk melaksanakan pembimbingan program pelaksanaan lapangan mahasiswa PGSD.

Pengembangan bahan ajar ini melalui uji validasi materi, uji validasi media, dan focus group discussion (FGD). Pada validasi materi diperoleh skor ratarata 2,35 (cukup) pada uji pertama dan rata-rata menjadi 2,6 (baik) pada uji kedua, sedangkan pada uji validasi oleh ahli media diperoleh skor rata-rata 2,6 (kategori baik) pada uji pertama dan 3,6 
(kategori sangat baik) pada uji validasi kedua. Adapun rata-rata hasil penilaian keterbacaan pengguna, dalam hal ini, dosen PGSD yang terkait dengan isi bahan ajar, yaitu dosen tentang konsep diverse learner (3,0- baik). Pendidikan matematika SD (3,53- kategori sangat baik), dan Pembelajaran IPS di SD (3,0baik). Dengan demikian diharapkan bahan ajar ini menunjang pelaksanaan PPL mahasiswa PGSD dalam mempersiapkan mereka melaksanakan pembelajaran yang mengakomodasi diverse learners di sekolahnya masing-masing.

Berdasarkan hasil penelitian dan kesimpulan, terdapat beberapa hal yang dapat disarankan: 1. Kepada dosen PGSD sebaiknya dapat mempersiapkan mahasiswa PGSD dalam melaksanakan PPL di SD dengan memperhatikan keberagaman siswa. Bisa dengan memberikan penugasan kepada mahasiswa pada masa pra-observasi untuk lebih mengenal siswa-siswa yang dihadapinya. 2. Kepada para mahasiswa PGSD yang akan melaksanakan PPL agar dapat menggunakan buku ini sebagai wawasan tambahan terkait keberagaman siswa dan bagaimana melaksanakan pembelajaran yang mengakomodasi keberagaman mereka. 3. Kepada peneliti berikutnya agar dapat melakukan pengembangan bahan ajar ini sehingga contoh implementasi pembelajarannya menjadi lengkap pada lima bidang studi di Sekolah Dasar.

\section{DAFTAR PUSTAKA}

Bates, A. J. \& Rosaen, C. (2010). Making Sense of Classroom Diversity: How Can Field Instruction Practices Support Intern's Learning? Journal Studying Teacher Education. Vol 6 (1), pp. 45-61.

Gall, M. D., Gall, J. P., \& Borg, W. R. (2003). Educational Research: An Introduction, seventh edition. Boston: Pearson.

Dimitrova, M., Sadler, C., Hatzipanagos, S., \& Murphy, A. (2003). Addressing Learner Diversity by
Promoting Flexibility in Elearning Environments. Proceedings of the 14th International Workshop on Database and Expert System Applications. DOI 10.1109/DEXA.2003.1232037. 